\title{
Esophagus and Esophagogastric Junction Cancer Pathologic Regional Lymph Nodes TNM Finding v8
}

National Cancer Institute

\section{Source}

National Cancer Institute. Esophagus and Esophagogastric Junction Cancer Pathologic Regional Lymph Nodes TNM Finding v8. NCI Thesaurus. Code C133385.

A pathologic finding about one or more characteristics of esophagus and esophagogastric junction cancer, following the rules of the TNM AJCC V8 classification system as they pertain to staging of regional lymph nodes. 